\title{
Tensions in Islamic Economics
}

\author{
Edward Mariyani-Squire* \\ School of Business \\ University of Western Sydney, Australia \\ Brouke St, Richmond NSW 2753, Australia \\ E-Mail: E.Mariyani-Squire@uws.edu.au
}

\begin{abstract}
The discipline of modern Islamic economics is currently torn in opposing directions by different visions of what its nature should be. On one side, it is argued that modern Islamic economics is too heavily influenced by secular economic theory. On the other side, it is argued that an overreliance on theologically-informed ideals would render Islamic economics unduly unrealistic. This paper explores the two competing criticisms of modern Islamic economics, illustrating how the conflict is played out in the area of Islamic banking. A case is tentatively made for greater pluralism in modern Islamic economics as a means of moving the discipline forward.
\end{abstract}

Keywords: islamic economics, islamic banking, modern islamic economics.

\section{OVERVIEW AND DEFINITION}

Modern Islamic economics arose out of an confluence of factors. One factor is the field of fiqh dealing trading, lending, and employment contracts, state regulations over markets (such as price controls and limits on market concentration), and the collection and disbursement of tax revenue by the state. Another factor is the rise of Islamic 'reformism' in late 19th century India and Egypt. In the face of colonialism, this movement sought to look afresh at sacred texts in order to build modern, politico-economic structures. Although clearly informed by what they saw as unquestionably Islamic ethical principles, the reformists sought to incorporate European intellectual traditions into their modernizing visions. Thus the echoes of liberal, socialist and social democratic ideologies can be discerned in the visions of these early thinkers (Siddiqi, 1993; Zayd, 2006; Parray,

\footnotetext{
* Penulis undangan
}

2011). A related Islamic 'revivalist' movement in the 20th century opposed such reformism on the grounds that it was effectively secularizing and Westernising Islamic societies. The revivalist movement led by figures such as Sayyid Mawdudi and Mohammad Baqir al-Sadr instead called for a self-consciously non-Western and explicitly Islamic perspective on all matters, including both private and state economic institutions (Wilson, 1998; Chapra, 2004).

Neither the reformists nor the revivalists developed systematic theories of economic processes; nor did they formulate 'Islamic' policies based on rigorous empirical knowledge. Rather, their thought operated at the level of general 'visions' of normative politico-economic structures. In the 1970 s, in response to what were perceived to be inadequate epistemic foundations for constructing a distinctly Islamic 'worldview', calls were made for the 'Islamicisation of knowledge' (Al-Faruqi, 1982). This entailed critiquing and replacing foundational 
Western categories and concepts with Islamic ones so as to entirely reconstruct all disciplinary knowledge on an on a sound theological basis. Needless to say, knowledge of economics fell within the project's purview. Inspired by the revivalist movement, but (usually) trained in the Western tradition of mainstream economics, a new breed of Muslim economists began to construct modern theoretical representations of what an Islamic economy would look like. This latest movement has grown apace and now holds regular conferences, is represented by the International Association for Islamic Economics, has a number of specialist journals, has produced numerous books and reports, and has facilitated the creation of university departments and institutes devoted to research on Islamic economic issues (Nagaoka, 2012).

Like all relatively young disciplines, a consensus on the definition of modern Islamic economics has not yet emerged. Rahim (2007: 7-9), for example, identifies seventeen different definitions. There seem to be as many definitions of Islamic economics as there are Muslim economists - maybe more. Fortunately, Mirakhor (2009: 32) offers a definition that captures most of the elements found in these various classificatory efforts:

... Islamic economics can be considered as a discipline concerned with: (a) the rules of behavior (institutions) prescribed by Islam as they relate to resourceallocation, production, exchange, distribution and redistribution; (b) economic implications of the operations of these rules and; (c) policy recommendations for achieving rules compliance that would allow convergence of the actual economy to the ideal economic system envisioned by Islam.

One will note that this definition resonates with secular definitions of economics by virtue of its concern with 'resource allocation, production, exchange, distribution and redistribution'. One may further note recognition of the familiar distinction between positive and normative realms, but also an implicit acknowledgement that the two realms are inextricably linked. Ethical foundations prescribe the 'rules' governing the boundaries of acceptable behaviour, but the explicit concern with normative policy formulation (how to manifest an ethically ideal economy) entails 'positive' knowledge of how an actual economy operates now and what the actual implications of the normative 'rules' would be if instituted.
As far as the English language literature on Islamic economics goes, a survey by Muqorobin (2008) shows that modern Islamic economics ranges over a wide variety of research topics. Macroeconomic topics such as fiscal policy, monetary policy and economic development are present, as is the construction of models of the macroeconomy. There is variety in microeconomic studies too, both theoretical and empirical, covering topics such as trade, insurance, real estate, trusts, marketing, labour, agriculture, corporations, and inheritance. However, work on banking and finance issues is by far the most predominant, making up almost $50 \%$ of all English language publications in Islamic economics over the period 1994-2005. It is also worth noting however that the second most prominent area of discussion - $19 \%$ of the English literature - is methodology and general theoretical frameworks. This material reflects the importance of debates over the evolution of Islamic economics. There are many ways in which the various methodological concerns and conflicts may be categorised. This paper focuses on the question of using theories and methods identified as 'secular'. On one side are those Muslim economists who base their work on secular theories and methods, but incorporate some insights from Islamic teachings. On the other side are those Muslim economists who regard such a framework as being illegitimate because it undermines or even violates ethical or epistemic principles of (what they regard as) a fully Islamic discipline.

\section{THE CHANGE OF COOPTION}

One type of critique of mainstream economics is that it falsely presumes its theories and policies to be universally applicable irrespective of the cultural, religious and societal contexts of people. Arguing that Muslim-majority societies produce people who have saliently different values, motivations and institutions, some Muslim economists have sought to modify the tools of mainstream economics to take into account these differences. They regard such an approach of scientific in the same sense that mainstream economics does because it entails the construction of theories which seek to describe, explain and predict economic phenomena. Such theorizing entails idealization and abstraction from reality, and theories are judged by the criteria of logical coherence and empirical 
veracity of predictions. Thus mathematical modeling and econometric testing are central methodological features of this endeavour. Rather than inventing entirely new theories, this approach tends to utilize theoretical content from mainstream economics, modifying it in various ways in order to 'Islamicise' it.

A number of Muslim economists have expressed serious concerns about the legitimacy of this approach to modern Islamic economics on the grounds that it has adopted secular economic theories and methods as core features, thereby betraying the 'Islamicisation of knowledge' project. Thus, so the argument goes, modern Islamic economics is not 'truly' Islamic because it merely borrows, and then cosmetically alters, mainstream secular economic theories. This criticism grew more strident from the 1990s onwards as it became clear that Muslim economists were often borrowing heavily from neoclassicism:

In attempting to ground itself on a theory of rational man and a hypothetical-deductive methodology ... [Islamic economics] has merely substituted Islamic terms for neoclassical ones, retaining the latter's assumptions, procedures and modes of analysis (Alatas, 1995: 95).

Despite such criticism, this trend seems to have continued. In 2011, Zaman summarized the the concern thus:

There is substantial evidence that the development of the discipline of Islamic Economics is currently in crisis ... [because] most Muslim economists have accepted too many of the ideas of Western economists uncritically. The methodological framework, and underlying assumptions are wrong, and in conflict with Islamic views (Zaman, 2011).

Whatever one thinks 'Islamic views' amount to, there is little doubt that at least some Muslim economists, reflecting their training, have assimilated mainstream theoretical constructs and models into their work.

For example, with respect to the conceptualization of Islamic consumer behaviour, one often finds the basic neoclassical theory of the rational utility maximizing agent used as a default framework, which is then modified to incorporate various Islamic themes. The standard neoclassical theory assumes an individual consumer maximises utility by choosing the most preferred a bundle of commodities given the resource available to them. Their preferences are exogenously given complete, transitive and continuous, and the available resources are limited such that the consumer is not satiated. To 'Islamicise' the theory, some salient modifications can be made. One obvious modification is to limit the bundle commodities to religiously permissible ones. This could be done by specifying preferences such that certain forbidden products such as wine, pork, etc. are 'discommodities' (less is preferred to more), or by specifying constraints such that forbidden products, despite being commodities, are not available (or have a price of infinity). Another possible modification is to incorporate preferences for 'otherworldly goods' - viz. rewards in the hereafter. If it is stipulated that there are otherworldly rewards for altruistic acts, then charitable purchases for the poor could, for example, be classified as a commodity entering into the preference set of the consumer. Alternatively, there could be a state-mandated poor tax (zakatt) that would constrain the private purchasing decisions of the consumer. In terms of the 'metaphysical drive' behind consumer behaviour, the concept of utility (thought of in terms of subjective psychological satisfaction) could be replaced by the theologically objective notion of pious belief. ${ }^{1}$

Another example of the appropriation of microeconomic neoclassical theory is Islamic models of private firms. Again, starting with a prioria of a profit maximizing firm (usually in the MarshallianPigovian tradition) with diminishing marginal returns in the short run and an average cost envelope in the long run, various modifications can be made to 'Islamicise' the theory. These modifications always involve firms either voluntarily restricting themselves to the production of permissible products or being compelled by law to avoid prohibited ones. Other modifications can include reconceptualisation of opportunity costs so as to include certain social obligations (either enforced by the state or by norms), or the relaxation of the assumption of profit maximization on the grounds that the pious entrepreneur will be interested in the welfare of consumers for ethical reasons (rather than due to the invisible hand of competition or as a mendacious marketing strategy). ${ }^{2}$

1 For examples of this kind of theorising see Zarqa (1980), Kahf (1980), Naqvi (1981) and Khan (1984).

2 For examples of this kind of theorising see Metwally (1992) Hasan (1998), Hasan (2002) and Amin and Yusof (2003). 
With respect to macroeconomics, one often finds some variation on the neoclassical-Keynesian synthesis used the theoretical basis of an 'Islamic' model of a national economy. For example, the IS-LM framework may be used to model a closed economy. The aggregate consumption function could include a compulsory poor tax (zakât); and instead of incorporating interest rates into the demand for money and investment functions, a profit-share ratio can be used; the money supply could be assumed to be fixed by the central bank. Default fiscal policy may be restricted to a balanced discretionary budget, and the poor tax could function as an automatic stabilizer. Monetary policy could operate through the manipulation of investment either via direct control over the reserve requirements of banks, or by altering its own profit-share ratio with private banks. ${ }^{3}$

Although it is true that the above modifications of orthodox secular economic theory - both micro and macro - have a clearly 'Islamic' tenor, this work has been criticized by for not going far enough. In particular, it is argued that some of the core features of secular theory remain essential to these economic models. With respect to microeconomics, for example, although charitable acts could be included in the consumer's utility function, the very concept of the utility function is essentially grounded in ontological, ethical and methodological individualism (cf. Choudhary, 1994). In brief, it may be said that rational decision makers behave in an outwardly selfless manner for covertly self-centered reasons, viz., their own personal satisfaction. In these models, agents do not help the poor because it is morally right in itself, as per the Islamic conception; rather, they do it because they seek satisfaction for themselves alone, either now or in the hereafter. As for macroeconomics, although some well known aspects of Islamic law are incorporated in the models (such as the implementation of the compulsory poor tax and the prohibition of interest rates), the standard orthodox objectives of economic growth, low unemployment and stable price rises remain the same. With respect to economic growth in particular, these models uncritically assume that this is beneficial to a nation's population. Such an assumption is questionable in that it presumes that wellbeing -

3 For examples of this kind of theorising see Mahdi and AlAsaly (1991), Yusoff (2006) and Ali and Myles (2010). both materially and spiritually - is facilitated by greater material production and consumption per se. It ignores long term environmental effects of capital accumulation, the effects on familial and social relationships of technological change and the 'more efficient' operation of labour markets, and the effects on culture and spirituality of an increasingly crisisridden materialist, consumption-orientated society (cf. Choudhary, 2006; Zaman, 2011). In short, the 'Islamic' augmentations to the standard secular micro and macro models are so $a d h o c$ and piecemeal as to effectively render the 'Islamic' prefix a mere veneer.

\section{THE CHARGE OF IDEALISM}

An alternative, more 'heterodox' approach to modern Islamic economics sees itself as remaining faithful to the 'Islamicisation of knowledge' project. It may be regarded as 'foundationalist' in the sense that it argues Qur'ānic and Prophetic ontological, epistemological and ethical foundations are essential to any 'truly' Islamic economics. With such foundations in place, distinctly Islamic economic institutions governing property and labour rights, money, financial and goods markets, and state revenue-expenditure can be put in place, thereby making manifest the good outcomes, both individually and socially, of Divine Law. Since all 'secular' economics is built on different foundations, it methodology and content must be rejected outright as fundamentally false and morally retrograde.

For example, Furqani (2010) argues that homo economicus, even modified, is unsatisfactory. He suggests that human behaviour should be explained not in terms of self-interest, but in terms of adherence to justice or rights (huquiq); private utility should be replaced with the public interest (maslahah) as the underlying motivator of behaviour; and rationality should be replaced with piety $(\operatorname{taq} w \bar{a})$ as the principle virtue of human beings. Asutay (2007a, 2007b) goes further. He argues that homo Islamicus can only make sense within a wider Islamic politico-economic context. He thus proposes an alternative set of 'axioms' which should inform all Islamic economic analyses: recognition of God's unity and sovereignty over all things (tawhīd) and humanity's vicegerency on earth (khilafah). This entails the following of a perfected path to social harmony (rububiyyah) 
that manifests justice and beneficence ( $a l$ ' $a d l$ wa'l ihsan) based on free will (ikhtiyar) constrained by obligations of Divine Law (fard). From these principles, says Asutay, perfection via purification (tazkiyah) and ultimately material and spiritual success (falah) will follow. Choudhary $(1999,2003)$ argues that at best 'mainstream' Islamic economics has only incorporated certain Islamic institutions in a piecemeal, ad hoc fashion, rather than developing a comprehensive holistic Qur'ānic worldview based a unified ontology and epistemology of ultimate unity (tawhīdi conception) built on an iterative social shuratic process of discovery regulated by majority consensus (ijma). Meanwhile Zaman (2011) argues that a variety of mainstream economic presumptions need to be replaced by Islamic ones which contradict them. For example, economics should be about transforming human values and institutions, not merely describing or explaining or predicting status $q u o$ actions and outcomes. It should include spiritual development and moral education as goals. It should be praxis orientated: viz. it should first and foremost seek to combat oppression, exploitation and injustice both as an end in itself and as a means of gaining knowledge. Generosity rather than selfishness should be fostered as the 'default' characteristic of economic agents, and competition alone should be replaced with cooperative institutions or at least limitations on extreme market competition.

Given the above criticisms leveled against those economists who would seek to utilize 'Islamicised' versions of orthodox economic theory, why then has modern Islamic economics not fulfilled the mission of the original 'Islamicisation of knowledge' project? Why hasn't an entirely different, thoroughgoing 'Islamicised' theoretical framework emerged in order to understand economic phenomena anew and formulate innovative economic policies? The answer would seem to lie in a general counter-position: viz. efforts to build a 'truly' theological and juridical Islamic economics is infused with a religious idealism that gives rise to unrealistic predictions and prescriptions.

With respect to theories, often the claims to the 'demonstrable' superiority of Islamic economicsbased institutions are based on deductions from axiomatic constructs. These axioms are either taken to be self-evidently true or are stipulated as ideal theoretical benchmarks. They usually posit imaginary, perfectly pious agents and institutions that follow the sharī'ah (as understood by the author positing the axioms).

For example, in his discussion of the definition of Islamic economics, Arif (1985a: 84) posits the following:

The representative economic unit in an Islamic society is a Muslim - one obedient to Allah. ... [H] e always follows the injunctions and the rules of the Shari'ah in all walks of his life. ... If we accept that the Islamic economic system is based on Shari'ah paradigm, then what interests us, as economists, is the behaviour of the [Muslim] economic agents in an Islamic society.

However, there is almost unanimous consensus that no actually existing nation-state is populated entirely (or even substantially) by people who 'always follows the injunctions and the rules of the Shari'ah in all walks of ... life'. Nor are any actually existing nation-states' laws entirely based on and perfectly implemented in accordance with the sharì'ah (however it is conceived). This being so, Arif's ideal conception of Islamic economics would mean that theory would be restricted to 'explaining' the behaviour of non-existent agents in a non-existent economic system. For such a theoretical construct, 'tests' based on econometrically specified models would be of very limited value because such models rely on data derived from non-ideal states that do not conform to the crucial ideal conditions. In short, such idealisations are strictly empirically unfalsifiable. For this reason, the only relevant criteria by which an idealized axiomatic Islamic economic theory could be judged would be: (a) internal logical coherence and (b) the degree of correspondence to a preferred interpretation of religious texts (Qur'ān, ah a dìth, and perhaps selected works of fiqh).

Criterion (b) in particular gives rise to at least two challenges. One is the fact that the Qur'ān, ah àdìth, and the works of figh are extremely wide ranging, and especially in the case of fiqh, reflect diverse opinions on many topics. Further, a truly ideal model would need to incorporate all the relevant elements relating to economic concerns. It would be insufficient, for example, to construct an economic theory that only abolished interest from the banking sector. This would give at best a highly incomplete 'Islamicisation' of 
theory, and at worst would amount to an ad hoc and piecemeal representation to Islam itself. A 'truly' Islamic economic theory would have to incorporate a variety of sub-theories including: permissible labour contracts, trade contracts, loan contracts, land tenure contracts, the conditions under which regulations over market prices are permissible in the cases of gluts and shortages, possible regulations over oligopolistic collusion and monopolistic and monopsonistic behaviour, a permissible system of taxation and revenue disbursement, the permissibility of public works by the state and private trusts. Also, various final economic objectives to be met by the acceptable means would also need to incorporated, including for example: poverty alleviation, employment, price stability, environmental sustainability, nonexploitation, and social harmony. The general economic theory would need to ensure that the combined sub-theories of permissible behaviour generate outcomes corresponding to the final objectives. This is an exceedingly tall order.

The other challenge is the delicate question of the correct interpretation of religious texts, and who has the authority to interpret the texts. It is well known that there are many ways in which religious texts can be read, and so an extremely wide variety of possible implications to be derived from them. One way in which the variety can be limited, but certainly not eliminated, is to say that hermeneutic authority lies exclusively with the orthodox and qualified scholars ('ulam $\bar{a}$ ) alone. Others however, may argue that in the modern period, the 'ulama' ' have not come to grips with the scientific and technical knowledge required to render relevant judgments in an exceedingly complex, ever-changing economic system. For example, some argue that fat $\bar{a} w \bar{a}$ identifying rib $\bar{a}$ with bank interest (as opposed to usurious rates) is based on a mistaken conflation of the modern economic concept of interest with medieval conceptions of money and money lending practices that are largely inapplicable in the modern period (e.g. Rahman, 1964; Saeed, 1999; Kuran, 2004; Shams, 2004; Šrámek, 2009).

One may seek to counter the criticism of empirically innocent idealisation by arguing that actually existing Muslim-majority societies can be progressively altered to conform to the ideal simply by imposing sharì'ah-based regulations and institutions. However, it may be counter-argued that beliefs about the beneficial results of such reforms are still overly optimistic, even to the point of being naïve. Such skepticism is grounded in the observation that the behaviour of 'actually existing' Muslim institutions and agents may turn out to be crucially at variance with the theoretically ideal Islamic institutions and agents assumed by advocates of shari'ah-based policies. This is one of the main complaints that Kuran (1986, 1989, 1995) makes of Islamic economics. Holding to a decidedly more pessimistic view of human nature than Islamic economics, Kuran argues that the acquisitive motive cannot be discounted if one wants to give a realistic account of and make plausible predictions about any society, including one populated by Muslims. ${ }^{4}$ On this view, it is entirely possible that at least some citizens populating a real Islamic state may behave in strategically self-centred ways so as to avoid or even manipulate sharì'ah rules to their own economic advantage. Since advocates of Islamic economics sometimes do not seriously contemplate this possibility, they may be blind to, or may even end up defending and promoting institutions and policies that in fact (inadvertently) undermine Islamic ethical principles.

Take the example of zakāt. Zakāt is a religiously mandatory tax that is paid annually by Muslims with sufficient wealth (of certain specified forms) to a variety of stipulated recipients. ${ }^{5}$ It is widely held that if this tax were collected and distributed

4 This is not to say that Kuran regards people, Muslims included, as essentially selfish and nefarious strategists. Rather, he seems to assume a dualistic human nature - one that is torn between selfless and selfish motives, where a sense of (socially mediated) guilt can play a motivating role.

5 In the Shafi'i madhhab, the forms of wealth liable for zakāt including tax rates are: agricultural livestock (1-3.75\%), gold/silver excluding jewellery $(2.5 \%)$, found or mined gold/silver $(20 \%)$, trade goods $(2.5 \%)$, nonirrigated staple food crops produced in that year (10\%), irrigated staple food crops produced in that year (5\%). Eligible recipients of zakāt payments include poor and the involuntarily unemployed Muslims, zakāt administrators, recent converts rejected by their families, Muslims with weak faith or who have peers that may convert (including teachers and proselytisers), Muslim slaves so they can purchase their own freedom, Muslims in debt for morally good reasons, unpaid Muslim military volunteers, and Muslim travellers in need of money (see Nawawi \& Keller, 2004: 71-79). 
systematically in accordance with the shari'ah, then the degree of income inequality and poverty plaguing many Muslim-majority countries could be substantially diminished (Khan, 1991: 259; Mahdi \& Al-Asaly, 1991: 65). However, aside from the fact that there is no consensus in the modern period on who, Islamically speaking, is 'poor', there is also no consensus on precisely how zakāt proceeds are to be divided up between worthy potential recipients. This leaves room for the possibility of selfish strategic decision making. For example, it is entirely possible for less-than-perfect zakāt administrators to distribute a disproportionate amount of revenue to themselves based on the legally legitimate claim that they should be paid a 'fair' money wage commensurate with comparable administrative positions. They may also entirely legitimately devote a large proportion of zakāt proceeds to teachers and students of private Islamic schools, which may happen to be attended by the children of the nation's economic elite. What little remains of the zakāt funds would then go to the destitute. Ironically, the result could be that a halāl disbursement of zakāt, which is rhetorically touted as the poor's claim on the resources of the wealthy, actually benefits the wealthy to a greater extent than the poor. A defense of a halāl disbursement of zakāt by proponents of Islamic economics on the theoretical assumption that agents are perfectly pious and altruistic when it comes to zakāt, could thereby end up defending systematic increases in economic inequality, to say nothing of further entrenching structural inequalities via subsidisation of the education of the economic elite's children. ${ }^{6}$

Khan (1991: 259) acknowledges that there can be and in fact are problems with the administration of zakāt, but seems to believe this is the only barrier to zakāt 'providing social security, eradicating poverty, and stimulating the economy.' This, however, is also overly optimistic and idealistic. A simple empirical examination of the application of the traditional criteria for sourcing zakāt funds in the modern world reveals that the monies generated in a number of Muslimmajority countries are woefully inadequate to deal with the substantial rates of poverty they face. Kahf (1989: 16), for example, reported that as ... applied on livestock, agriculture, mining and monetary holdings,

6 For depressing evidence of this in Malaysia's state-run distribution of zakāt funds, see Kuran (2004: 25).
Zakat proceeds [for Egypt, Indonesia, Pakistan, Qatar, Saudi Arabia, Sudan, Syria, and Turkey] would be between $0.9 \%$ and $2 \%$ [of nominal GDP] (except in Sudan where it is $4.3 \%$ ). ... Hence, even if all of Zakat is given to the poor, it will not be sufficient to provide them with minimum biological sustenance in most Muslim countries today, let alone enriching them.

Even if a more liberal criterion for sourcing zakāt funds is used (which includes salaries taxed at 2.5\%, fixed capital and net returns thereon taxed at up to $10 \%$ ), the funds generated - between $1.7 \%$ and $7.5 \%$ of GDP - would still be inadequate given the relatively high poverty rates and relatively low levels of GDP per capita in many Muslim-majority countries (Kahf, 1989: 18). An examination of national accounts up to 2007 reveals these results to be little different, ranging from $\sim 1.3 \%$ of nominal GDP for Saudi Arabia to $\sim 7 \%$ of nominal GDP for Syria. Taking the most povertystriken case of Sudan, where $44 \%$ of the population in 2007 lived on less than US\$2 per day, if all Sudan's potential zakāt revenue went to the poor, then each poor person would receive only US\$172. Comparing that to the Gross National Income per person in 2007, which was a meager US\$2160, one realizes that the institution of zakāt does not even begin to ameliorate let alone eliminate poverty in Sudan. Worse, the structural shifts in capital formation mean that the traditional zakāt structure could in fact promote greater inequality because it is mostly poor households (effectively peasants) in many Muslim majority countries who are concentrated in zakāt-liable agricultural production, whereas wealthy households are concentrated in the growing zakātfree manufacturing and services sectors.

In sum, although the 'Islamicisation ofknowledge' project for modern Islamic economics may be wellintentioned, without empirical knowledge of what can and does occur in actually existing Muslim-majority societies, its prescriptions are liable to verge on the utopian, and the implementation of them is liable to lead to harmful unintended outcomes which are morally unacceptable by Islamic standards.

\section{CONFLICT OVER ISLAMIC BANKING}

The conflicting perspectives on the appropriate direction for Islamic economics is borne out most starkly in the area that has most preoccupied the discipline of Islamic economics - viz. banking theory 
and practice. On one side it is argued that Islamic banking is insufficiently 'Islamicised' because it has evolved in a way that essentially mimics conventional banking. On the other side it is argued that in order to have a viable Islamic banking sector, it has been necessary to respond to the realities of the market place - that the idealized account of Islamic banking simply cannot exist in the real world.

\section{The charge of mimicry}

In theory, an Islamic bank functions as a coordinating intermediary between depositors with excess capital and capital-poor entrepreneurs. The bank acts on behalf of depositors to select potentially profitable sharì'ah-compliant ventures in which to invest. The bank is passive in the sense that it waits for entrepreneurs to offer-up ventures rather than seeking them out, but is active in the marketplace in the sense that it seeks to attract ventures by means of a variety of competitive product-contracts. The main types of contracts would include partnership-based contracts (mushärakah and mud ärabah), ${ }^{7}$ asset salebased contracts (murābahah, al-ijārah wa iqtinā, bay bi taman ajil), ${ }^{8}$ and collateral-based contracts (rahn

7 For mushärakah contracts, both the bank and the active entrepreneur invest some amount of capital into the business. The bank acquires some share of whatever profits-losses are made by the business in accordance with the share of capital provided minus some amount that goes to the entrepreneur for their efforts and skill. The operating capital provided can change, as can the profit-loss share if provision is made for such change in the contract. For mud arabah contracts, the bank provides all the initial capital and the entrepreneur utilises it. Profit from the business is shared according to pre-specified proportions negotiated before the contract is written. This will usually specify some amount (or percentage) of profit that goes to the entrepreneur for their efforts and skill with the remainder going to the bank. All losses are borne by the bank.

8 For murābahah contracts the bank gives money to an individual to purchase an asset at the market price P. The asset is formally owned by the bank, who then on-sells it to the individual at an agreed price $\mathrm{P}^{*}=\mathrm{P}(1+m)$ where $m$ is a percentage profit mark-up. The other contracts are variants on this structure. For bay'bi taman ajjil (deferred payment sale, also known as bay' al-muajjal) contracts, the bank buys an asset at market price $\mathrm{P}$ on behalf of an individual who then incrementally purchases the asset from the bank over some agreed period of time to the value of the original purchase price plus a percentage profit markup. For al-ijārah wa iqtinā (rent and purchase) contracts, the bank buys an asset (chosen by the customer) at market and bay' al-'inah). ${ }^{9}$

In theory, what defines these contracts as 'Islamic' is that they comply with the following conditions: they are based on the sale/purchase of (a) a physically existing halāl asset and (b) there is a proportional sharing of losses and a voluntarily agreed upon sharing of profits between fully informed parties. This entails a prohibition on rib $\bar{a}$ (interpreted as usurious interest payments or interest payments per se), gambling, including price speculation (maysir), and ambiguity in essential terms or conditions of a contract (ghurūr) (see El Hawary, Grais \& Iqbal, 2004: 5; van Greuning \& Iqbal, 2008: 6-10).

In theory, thanks to these well-known conditions, it is fairly clear what is permitted and forbidden in the sharī'ah with respect to trade and financial transactions. This gives the legal certainty required for rational investment and savings decision making through time and thereby provides the basis for greater economic stability. To ensure that their products are in conformity with the sharíah, Islamic banks must consult with and gain approval from one or more recognized Islamic jurists.

Mushārakah and mud ārabah (partnership) contracts are widely regarded as the ideal halāl banking products, and in the 1970s were optimistically projected to become the predominant kind of contract offered by Islamic banks. Banks would act as the representatives of the investor-depositors who would effectively be shareholders in business ventures for which capital was provided by banks. The actual economic profits and losses would be shared according to the proportion of capital contributed by the bank. This was regarded as the 'essence' of Islamic banking on the basis of elementary ethical claims: since there is a partnership arrangement, profits and

price $\mathrm{P}$ and rents it to the customer over a specified period, thereby paying total rent of amount $r \mathrm{P}$ where $r$ is a percentage rental rate. The customer contracts to purchase the asset at the end of the specified period for P. Thus the customer will effectively pay the original purchase price plus rental mark-up $\mathrm{P}(1+m)$.

9 For rahn contracts, the bank holds an individual's asset as collateral, giving the individual some agreed amount of money as a 'benevolent' loan which they then pay back at some future agreed upon date (whereupon they obtain their asset back). For bay' al 'inah contracts, an individual sells an asset to the bank at a market price $\mathrm{P}$, and at a later date the bank sells the asset back to the individual for $\mathrm{P}+\mathrm{M}$. 
losses are shared fairly; the banks would not 'exploit' or 'destroy' an unfortunate 'borrower'; and the bank depositors (the principal 'lenders') would not obtain a risk-free return for no effort, thereby avoiding the connotation of a parasitical relationship (Boudjellal, 2006).

In practice, however, it has turned out that partnership contracts in fact comprise a tiny fraction of total assets of major Islamic banks. Šrámek (2009), for example, found that less than $10 \%$ of total assets of 18 Islamic banks from around the world were devoted to genuine profit-loss sharing contracts. Most loanable funds are instead devoted to murābahah (asset sale debt-based) contracts. Yousef (2004) calls this the 'murābahah syndrome'. Šrámek's research suggests only the slightest of changes in the proportion of such contracts from 2003 to 2007 (with the exception of Indonesia). Profit-loss sharing partnership contracts are thus only the 'essence' of Islamic banking in the marketing sense; they are not really essential to the existence of Islamic banking.

Aside from the disjuncture between the public face of Islamic banking and the reality of its practices, there is also criticism of murābahah-type contracts in themselves. The criticism of such contracts is that they seem to violate some basic substantive features of traditional Islamic trade contracts upon which they are based. The major problematic features of such contracts are that, in practice, (a) the potential buyer of an asset from the bank (which the bank funded) is contractually obliged to purchase the asset when offered; (b) the bank is generally guaranteed regular profit or rental payments by the customer; (c) the bank generally avoids risk of loss by means of insurance or stipulations in the contract that place risk-burdens (such as due to damage) on the customer; (d) the profit or rental payments are unpredictable in those cases where the bank contractually stipulates the right to alter the profit/rental rate in each new payment period; (e) the changes in profit/rental payments need not be tailored to the income capacity of the customer; and (f) the profit or rental rates amount to interest rates (Saeed, 1998). All of these features are explicitly prohibited on a traditional interpretation of the sharì'ah. Point (f) - perhaps the most visibly controversial feature of modern contracts - becomes transparent when banks' 'profit' and 'rental' rates are explicitly linked to the same interest rate benchmarks used by conventional banks. For example, Pakistani Islamic banks link the profit ratios in their contracts to the Karachi Inter Banks Offered Rates (KIBOR). Similarly, the Dubai Islamic Bank calculates its rates based on the Emirates Interbank Offered Rate (EIBOR). The same is true with the sovereign sukūk bonds of Qatar, Malaysia and Pakistan, which peg their rates to the LIBOR or the KIBOR (Siddiqui, 2006). ${ }^{10}$

Further, there are also questions about whether the most favored mushārakah and mud arabah contracts really live up to the 'spirit' of the sharī'ah in practice. In the case of mud arabah contracts, although originally envisioned to be venture-capital contracts in which the entrepreneur would have freereign, such contracts in fact appear to be mainly used for short-term trading activities for specific goods, and are fairly strictly controlled by the bank (including the time period and management of the venture). Further, such contracts are usually written in such a way that the bank can seek damages from the customer-entrepreneur if the contract is terminated by the latter (usually due to a failure of the venture). By these means, the bank shifts risks to the customerentrepreneur and ensures a known return on its capital. Similarly, for mushārakah contracts, banks seem

10 These criticisms apply to the other asset sale-based contracts too. For al-ijārah wa iqtinā and bay'bi taman àjil (deferred payment sale) contracts, which often function as real estate and personal loans, the bank, being the initial majority owner of the asset (say, a house or a car), decides the future value of the asset and the increments to be paid by the customer in order to gradually become the owner of the asset and charges a rental rate to the customer (the purchaser) for the use of the asset. This rental rate is highly correlated to the home-loan or personal loan interest rates of conventional banks. For example, Islamic financial institutions in Australia calculate their 'rental' rates based on the Reserve Bank of Australia's official cash rate or the London Interbank Offered Rate (LIBOR) (Ahmad \& Shahed, 2010). Further, the rental rate is virtually a compulsory payment that is largely independent of the financial circumstances of the customer (except in extreme circumstances), similar to conventional banks. With respect to rahn contracts which are popular in Malaysia, these essentially amount to pawn broking instruments that turn out to be less than 'benevolent' loans: banks charge customers a custodianship fee for holding the collateral that is directly related to the size of the loan and positively correlated with conventional bank interest rates (Dusuki \& Abozaid, 2007). 
to issue such contracts in a manner than effectively minimises their risks (ensuring expected returns) by shifting risks onto the customer-entrepreneur. As Saeed (1998: 92) put it:

Under Islamic banking, although musharaka is used in several forms, it is the short-term commercial form which has become prominent, where the contract is closely related to the purchase and sale of certain specified goods. The commercial musharaka enables the bank to recover its capital, plus return, without much uncertainty or risk. The partner [i.e. the customer-entrepreneur] is restricted, in his actions by the detailed terms of the contract, which do not leave him much freedom to conduct a musharaka in the real sense of the term as developed in fiqh [i.e. Islamic jurisprudence]. From the terms of the contracts of Islamic banks, it appears that the partner's function is to sell the goods involved at the price specified by the bank, in order to realise the return the bank is aiming at. The bank's share of capital and its return thereon is reasonably well protected by various forms of guarantees and terms of the contract. The bank also seeks various forms of guarantee to protect its interest in the venture and appears to attempt, where possible, to put a significant number of risks associated with the management of the musharaka onto the partner.

If this is the case, the general charge that since all Islamic bank products - including modern mushārakah and mud ārabah contracts - function in a similar way to conventional loans seems to carry weight. From this it would follow that although Islamic banking technically complies with sharī'ah regulations such as the prohibition on interest income and on the financing of harām activities, the substantive intentions of the shari' $a h$ are ignored in practice (cf. Dusuki \& Abozaid, 2007; Choudhury, 2008; Zaman, 2011; Asutay 2012).

Another criticism of Islamic banking in practice is that Islamic banks, contra conventional banks, are supposed to be particularly concerned with just socio-economically outcomes. Greater equality in the distribution of income and wealth, fair dealings by risk-sharing, ethical investment, and development programmes are regarded as distinctive normative features of Islamic banking. However, in practice, Islamic banks appear not to have lived up to these aspirations. Examining 25 countries, Asutay (2010) found no correlation between the growth of Islamic banking assets and changes in human development indices for any of these countries. He thus concluded Islamic banks have simply not contributed to investment in those fields that would foster economic development. Instead, just like conventional banks, rather than fighting the phenomenon of 'financialisation' that has gripped the US and Europe, Islamic banks have been willing and active participants in it (Asutay, 2012). It seems clear that the novel financial products such as tawarruq contracts, ${ }^{11}$ $\square u k \bar{u} k$ bonds, 'Islamic' derivatives and 'Islamic' futures - products only nominally connected to the real economy - have not been developed in order to benefit the poor, or to assist local small businesses, or in any way to generate domestic economic development, but rather are tailor-made to facilitate wealth-generation for corporations and the economic elite. Indeed, products that would help the poor such as microfinance loans and charitable loan contracts (qard al-hassan) ${ }^{12}$ appear to be unambiguously eschewed by Islamic banks (Rahman, 2007: 128-129; Jan, 2011).

Finally, it is argued by some that the institutional mechanisms by which new financial products are approved - viz. via banks' own sharī'ah advisory boards - do not function according to the ideals of

11 Tawarruq contracts basically operate in the following manner. A bank purchases an asset in a commodity market (steel, grain, gold, or whatever) at price $\mathrm{P}$, immediately sells the asset to an entrepreneur at a mark-up $\mathrm{P}+\mathrm{M}$ to be paid back over some period of time, and the entrepreneur immediately sells the asset in the market again at $\mathrm{P}$. The entire set of transactions is normally facilitated by the bank. The entrepreneur thereby acquires money $(\mathrm{P})$ quickly along with a debt $(\mathrm{P}+\mathrm{M})$. Businesses sometimes enter into such contracts when they face short-term liquidity problems. Loans for such purposes are generally regarded as being prohibited to Muslims, but since this is not technically a loan it may be regarded as a legal stratagem to avoiding condemnation. See Nagaoka (2012: 127-129)

12 Qard al-hassan loans are 'charitable' loans in the sense that they entail no requirement of compensation, mark-up, etc. for the lender. The borrower should seek to pay back the amount lent either in instalments or as a lump-sum when they are able to (as determined by themselves). Although the lender can make no demands on the borrower over and above the principle lent, the borrower may voluntarily choose to reward the lender for their generosity by gifting them some amount of money after the loan has been repaid. 
theory. Two important problems are the following. First, at present a relatively small number of Islamic legal scholars specializing in financial matters dominate the lucrative 'fatwtā market'. This gives rise to the danger of a perception of scholars being 'purchased' or at least subjected to the temptation of moral hazard (Khan, 2010; Ünal, 2010). Second, there is not perfect consensus ( $\left.i j m \bar{a} \bar{a}^{\prime}\right)$ on all matters relating to Islamic banking - especially new developments. There are a variety of scholarly opinions available on what can count as a valid form of contract. And sometimes past judgements by particular scholars or boards are reversed (Briault, 2007; Al-Amine, 2008; Malik, Malik \& Mustafa, 2011; Nagaoka, 2012). It is not unreasonable to suggest that as the number of scholars of sharì'ah grows with industry demand, the variety of innovative and divergent fatāwa will similarly grow. This undermines the certainties that are supposed to be provided by shari'ah-based transactions.

\section{The Case for Pragmatism}

Countering the above criticisms, some Muslim economists argue that in the real world of an increasingly global, competitive, and technologically advanced banking industry, it is simply not possible to maintain the standards embodied in the idealised theory of Islamic banking. Pragmatic compromises based on empirical realities need to be made in order for Islamic banking to exist at all. To remain viable private enterprises, Islamic banks must take into account and respond to the actual wants and needs of their potential clients. Since those clients do not themselves perfectly conform to the assumptions of theologically informed theory, to survive Islamic banks must modify their practices to take this fact into account.

The various potential clients of Islamic banks do not function in the same way as theory posits. In theory, potential depositors are of two types: households driven by a transactions motive and 'firsttier' investors driven by a profit motive. The former would have the nominal value of their deposits ensured, but would receive no return, as they would only be using the bank as a convenient way of temporarily holding money for transaction purposes. Investor-deposits would thus be the only source of funds for 'second-tier' investment. The return would not be fixed, but would rather depend on the share of profit garnered on their behalf by the bank investing in capital-poor businesses. In theory, 'second-tier' capital-poor clients are predominantly entrepreneurs seeking capital for permissible, productive investment in business ventures. They would honestly share their profits-losses with 'first-tier' investors, as facilitated by the banks. Since there is a correspondence between the risk preferences of the first and second tier investor-clients, and since household-clients make deposits for non-pecuniary reasons, the system should function relatively smoothly (Khan \& Mirakhor, 1989; Mirakhor, 2007, 2009).

In actuality, however, households are likely to be driven by transactions and precautionary motives, and first-tier investors are likely to be looking for relatively safe short-term returns on surplus capital (otherwise they would use their surpluses to invest in risky business ventures directly). Thus, both types of depositors are in fact likely to expect fairly stable returns on their deposits: households will expect stable returns to guard against the erosion of purchasing power, and investors will expect stable returns in order to minimise opportunity costs. Real depositors will thus tend to be relatively risk-averse. ${ }^{13}$

Potential second-tier capital-poor clients on the other hand, are entrepreneurs seeking capital for investment and households seeking capital for durable consumption goods (including dwellings). If Islamic banks were to specialise in profit-loss sharing partnership-based contracts (mushärakah or $m u \square \bar{a} r a b a h$ ), as the theorists of Islamic banking expected, then households would effectively be ruled out as potential clients (unless they were willing to treat their real estate purchases as speculative investments). This would leave only entrepreneurial investors as second-tier clients. That means banks would be entering into undertakings that are, for a number of reasons, inherently risky - and certainly riskier than conventional loan contracts. This is because the banks would face adverse selection and moral hazard problems in ways that conventional banks would not. Adverse selection arises because an entrepreneur taking on a high risk investment would prefer a loss-sharing contract over a conventional loan, and conversely, would prefer a conventional

13 To illustrate the point empirically, see Kasri \& Kassim (2009) for an analysis of the determinants of savings in Indonesian Islamic banks. 
loan for a low risk investment. Thus Islamic banks would tend to attract only high risk investors. Moral hazard arises because it is always possible for lessthan-perfect entrepreneurs to artificially inflate their costs in ways that enrich themselves and yet 'on paper' generate losses for their businesses. In this case, the bank would bear an explicit loss and the entrepreneur would make a covert gain (at the expense of the bank). To guard against such moral hazard, Islamic banks would have to engage in detailed monitoring of their partnerships, which would substantially increase their transaction and enforcement costs relative to conventional banks with which they compete. In sum, if entrepreneurs are not entirely honest and selflessly committed to Islamic ideals, profit-loss sharing partnership contracts may not merely be less profitable than the non-ideal contracts, but may in fact be loss-generating for banks (cf. Khan, 1989; Kuran, 1995; Adnan \& Muhammad, 2007).

The above real-world problem is the underlying reason why Islamic banks, whatever their initial noble intentions, have ended up resembling conventional banks by focusing on muräbahah-type quasidebt-based products and various kinds of quasiconventional securities trading. It is also why banks offer deposit and lending rates that track conventional interest rates; why they introduce service fees and charges; and why they engage in risk-shifting when writing contracts (cf. Yousef, 2004). It is also the prima facie reason why Islamic banks, contra the ideal, have avoided relatively poor entrepreneurs who wish to establish small businesses in agriculture and manufacturing and why they avoid giving charitable loans to the poor: at best such loans generate no profit, and in aggregate may result in losses for depositors (and owners). ${ }^{14}$

In short, the muräbahah-type products, to the near exclusion of all other shari'ah-compliant products, ensure stable and predictable returns in order to satisfy the preferences of risk-averse depositors, to remain competitive against conventional banks, and to avoid the possibility of insolvency in an economic downturn.

14 As Rahman (2007: 128-129) puts it with respect to microfinance: 'Concerns about the lack of real profitability of microfinance prevented banks from getting involved in microfinance. The inherent risks posed by microfinance and the widespread belief that the poor are poor because of their lack of skills, has kept traditional banks, including Islamic banks, away from microfinance.'
Can the divergence between the theoretical ideal and the actuality of Islamic banking be justified on Islamic legal grounds? The pragmatic position answers in the affirmative on two grounds. One argument appeals to the principle of maslahah - that is, an action is permissible if it secures moral benefits and/or prevents moral harm to the society, or more generally, ensures net social moral benefits. It may be argued that despite the imperfections in Islamic bank loan practices, they are nonetheless morally superior to the alternative because they avoid compound interest, are not as harmful to ostensible 'borrowers' who fall on hard times, avoid purchase of products or investment in harām businesses, and avoid extreme forms of destabilising speculation such as Ponzi schemes. In other words, Islamic banking may be classified as a 'lesser evil', which is always preferable to a 'greater evil'. The other argument relies on the claim to necessity (darūrah). Private Islamic banks are compelled to operate and compete in a globalised financial network which includes transnational, central and conventional local banks that operate according to principles of interest-bearing loans. For this reason, it is simply not possible for Islamic banks to completely avoid paying interest itself to other conventional institutions; nor can it avoid taking such interest payments into account when constructing its own products. Thus, so the argument goes, the legal maxim 'Necessity permits that which is forbidden' (darürah tubih al-mahzurat) may be said to apply, and a dispensation (rukhsa) would be given to Islamic banks. Until and unless a sufficiently comprehensive parallel banking and financial system comes into existence, Islamic banks may appeal to the darürah maxim.

Dusuki \& Abozaid (2007) dismiss these kinds of arguments on the grounds that insofar as the innovative 'Islamic' financial products violate the 'substance' of sharì' ah-and for them, the innovations do just that - then the appeals to the maslahah and darürah arguments are unsound. On the other hand, it must also be borne in mind that the fatāwa that sanction the various innovative practices developed by Islamic banks are not the product of ignorant and unqualified or mendacious amateurs. With the possible exceptions of some tawarruq, and bay' aldayn underlying some suku $k{ }^{15}$ innovations are in fact supported by genuine legal arguments based

15 See Rosly \& Sanusi (1999) and Hosen \& Nahrawi (2012). 
on the traditional methodologies of the established schools (madhāhib) of jurisprudence. Indeed, as Kahf (2004) points out, Islamic banks have tended to favour 'traditional' madhhab-following scholars over 'modernist' or 'revivalist' academics and proselytizers. Critics might not like murābahah-type contracts, may feel that they violate the 'spirit' of the Qur'ānic message and the Prophetic teachings, may believe them to be a capitulation to Western financial interests, and may judge them to be only cosmetically 'Islamic', but none of that changes the fact that these contracts are backed by authentic fat $\bar{a} w \bar{a}$ written and vetted by established scholarly individuals and bodies using traditional methodologies of fiqh. To effectively claim or imply that these fatāwa are deviant and without genuine legitimacy - especially when it is made by critics who are not themselves formally trained in the time-honoured traditions of one of the madhăhib-is not merely unconvincing in legal terms, but more broadly, is tantamount to calling a number of important national and international scholarly institutions heretical. ${ }^{16}$ Needless to say, such a claim would be extreme.

\section{CRITICAL REFLECTION}

A criticism that may be made of both of the above identified contending strands in Islamic economics is that they both seem to have a quite restricted conception of 'secular' economics. Too often, proponents of both sides identify 'secular' economics almost exclusively with a quite narrow conception of neoclassical micro and macro economics. One stand seeks to accommodate and modify it and the other stand rejects it outright - both apparently thinking that this is all there is to 'secular' economics. This entails two unhelpfully restrictive oversights.

\section{Heterogeneity in Secular Economics}

The first oversight is that neoclassicism is in fact an internally contested paradigm - there are different interpretations of what it claims, what it implies, and how it is developing. Critics often seem to focus

16 These institutions include the Fiqh Academy of the Organisation of Islamic Countries, the Sharìah Board of the Accounting and Auditing Organisation for Islamic Financial Institutions, the Sharì'ah Supervisory Advisory Panel of the International Islamic Financial Market, the Majelis Ulama Indonesia, and the Islamic Banking and Finance Institute Malaysia. on an interpretation that is prevalent in popular undergraduate US textbooks or one that is closely associated with the Chicago School. For example, Haneef \& Furqani (2009: 180-181) claim that:

Mainstream economics has established "homo economicus" or "economic man" as the ideal type of economic agent who will apply all assumptions of economics in real life...

Homo economicus is conceived as an individual who acts rationally by pursuing his own self interest and maximising his own utility. A person is seen as maximising his utility function, which depends only on his own consumption, and which determines all his choices. He is characterised by an individualistic self-interested, utility-maximising, "rational" characterisation, while any ethical consideration is an exogenous variable in his preference. This notion of individual behaviour constitutes the ethical foundation as well as micro-foundations of economics as a discipline where all economic theories and analyses are based on this concept of man.

This account fits relatively well with the preconceptions of a particular interpretation of neoclassicism once pervading the Chicago School of George Stigler and Milton Friedman. The Chicago School is not, however, synonymous with neoclassicism per se. Such an account of decision making may certainly be disputed by others who fall within the broad neoclassical paradigm, but who would seek to deploy the analytical tools of optimisation without pre-specifying the kinds of aims, constraints, or even the nature of the decision maker. To go straight to the point, the most elementary conception of the rational neoclassical agent is nothing more than the following: a decision making agent will choose options that are most preferred given the constraints faced. The theory does not specify the options preferred, the precise nature of the constraints, or even the nature of the agent. The choice options are often presented in textbooks and specified in journal articles as being quantities of goods/services for the agent themselves alone, the constraints are often presented as being the prices of the goods/services and income or wealth, and the agent is often presented as being an autonomous individual person. But these are not necessary presentations or specifications. For example, it is not constituent of the theory that an optimizer must be indifferent to others - it is possible for an agent to prefer to assist others - 
perhaps because they prefer other people to be happy over themselves. They may prefer to follow a moral imperative to help the poor than to spend income on themselves. Nor does it necessarily exclude the possibility of alteration of preferences in the light of new information, interaction with others, or newly emerging social norms. It is true that the preferences of the agent are still 'their own' and so the agent's actions are in that narrow sense 'self-directed', but this does not logically entail psychopathic selfishness (e.g. Caplin \& Schotter, 2010). It is precisely this broader conception of neoclassical axioms of rational decision making that informs proponents of modern Islamic economics who either develop what they regard as 'Islamic' conceptions of the rational agent, or test the effects of sharì'ah-based policies.

That said, it does not follow that there are no problems with the neoclassical conception of decisionmaking and thus with the neoclassical conception of decision-making of Muslims. One obvious problem is that of 'realisticness'. It has always been problematic to claim that any human being actually makes the kinds of mathematically precise optimisation calculations presumed by neoclassical theory. As has been pointed out many times in different ways - perhaps most famously by Veblen (1898), Keynes (1936; 1937) and Simon (1955) - human beings simply don't possess the cognitive capacities required to engage in such decision-making. Historically contingent customs, habits and heuristic norms are offered as better explanations of actual decision making. A related criticism is that standard theory has little to say about changes in (and firms' manipulation of) preferences, which can obviously play a significant role in explaining microeconomic phenomena (Galbraith, 1967). Certainly behavioural and experimental economics, which finds that actual human beings behave in 'anomalously' irrational ways (both in the consistency sense, and in the 'selfish' sense), is making some progress in transforming mainstream economic theory (Bardsley, Cubitt, Loomes, Moffatt, Starmer \& Sugden, 2009). And what is to count as reasonable and prudent (as opposed to narrowly rational) decision making may depend on a whole host of factors, including both risk preferences and moral values. If such factors are not incorporated into a theoretical representation of agents, one is liable to systematically misunderstand actual decisions (Broome, 1999). As to what those preferences and values in fact are, however, is a strictly empirical matter. It cannot be determined a priori.

In sum, it may well be true that a narrow and unsophisticated conception of utility and profit maximizing agents is both morally unacceptable and empirically inadequate for the purposes of a normatively informed Islamic economics, but it does not follow that everything in neoclassicism - especially more recent theoretical and empirical developments - should be rejected too, especially if such developments are useful to obtaining ultimate normative ends.

The second oversight by much of Islamic economics is that it narrows the field of possible alternatives to just neoclassicism and the neoclassicalKeynesian synthesis. It thereby fails to acknowledge and engage with Post-Keynesian, Institutionalist, Ricardian political economy, neo-Marxian, and Austrian schools of thought, which hold quite different positive and normative conceptions of economic structures and relations to orthodoxy (Stilwell, 2006). Given that these alternative heterodox schools have not been engaged with in an in-depth fashion makes it difficult claim that they are irrelevant or useless to modern Islamic economics.

The failure to engage with these heterodox schools is unfortunate because their insights because it is entirely possible that modern Islamic economics could indeed benefit or could at least draw some inspiration from them. First, these heterodox schools, some being over a century old, have had time to develop a wide range of substantive critiques of neoclassicism on methodological, logical and empirical grounds. If proponents of Islamic economics see the dominance of neoclassicism as a problem, one would expect them to investigate and mine these large, already existing bodies of work. Second, the heterodox schools share some broadly similar methodological concerns with modern Islamic economics - viz. the recognition that ideologies pervade economics as a social science, and the necessity for an interdisciplinary approach that incorporates social, political and ethical elements as essential to a more complete understanding of economic phenomena and solutions to problems. Third, the heterodox schools share some similar normative objectives with Islamic economics, especially related to poverty, wealth and income inequality, environmental destruction, exploitation of labour, and systemic crises of capitalism. And 
finally, the heterodox schools recognize that the analysis of institutionalized power structures political, economic and cultural - is necessary in order to understand how economic systems evolve and what barriers to ethical goals exist. The last of these - what may be called a politico-economic analysis - is conspicuously marginal in the modern Islamic economics literature. One finds, for example, very little discussion of the highly asymmetric nature of labour-capital power relations, the exploitation and discriminatory practices in labour markets, and the links between corporations' economics interests and the formation of labour laws in Muslim-majority countries. The related topic of poverty as received somewhat more attention in Islamic economics, but still, there has been little by way of substantive analysis of the material economic interests, structural economic changes, and the relations between corporate power and state corruption (both overt and covert) which fundamentally contribute to the creation and maintenance of pervasive poverty in Muslim-majority countries. Given the human costs of poverty in terms of infant mortality and lower average life expectancy alone, both in Muslim and non-Muslim societies, one would have thought this topic would be the most pressing and prominent topic in modern Islamic economics. Instead, the greatest focus by orders of magnitude has been Islamic finance - a topic that is by and large of greatest interest and benefit to an economic elite seeking to 'halālise' its economic surpluses.

\section{Pluralism}

As suggested above, modern Islamic economics of all types could benefit from openness to other schools of thought, including 'secular' ones. Indeed, one may tentatively suggest that such openness to a plurality of schools is itself consistent with an Islamic perspective.

Pluralism in a broad sense is clearly indicated in the Qur'ān (2:148, 5:48, 21:92-93, 23:51, 49:13) as being ordained. The above cited passages point to different kinds of pluralism: different tribal groupings, different cultural mores and ways of life in general, different degrees of revelation, different legal systems, and different understandings (and misunderstandings) of divine ethics. One may speculate that insofar as one can conceptualise economics scholars as a group, it too exhibits plurality: there exist many sub-groups with different worldviews of how economic systems do and should function. Given the ordination of plurality more generally, one may say that a plurality of schools within the broad community of economics scholars is to be expected. As to the appropriate response to such pluralism, Muslims (at least) are commanded to 'Vie, then, with one another in doing good works' (Qur'ān, 5:48), which logically entails that one not ignore or dismiss out of hand what others seek to achieve, but rather understand, take into account, and respond to other groups in the most beneficial way. The implication that gaining understanding and knowledge via plurality is an imperative is reinforced in the passages 'And of His signs is the creation of the heavens and the earth, and the difference of your languages and colours. Lo! herein indeed are portents for men of knowledge' (Qur'ān, 30:22) and 'We have created you all out of a male and a female, and have made you into nations and tribes, so that you might come to know one another' (Qur'ān, 49:13).

The epistemological keys to this pluralistic 'unity in diversity', especially as it relates to ways of systematically (or 'scientifically') conceptualizing and analyzing the social world (including its economics), is fallibilism and instrumentalism.

Fallibilism is the position that humans do not necessarily possess perfectly complete or perfectly accurate knowledge, especially when it comes to empirical questions. TheQur'ān fairly clearly indicates that people are fallible beings. The story of Mūsa and Khidir is a striking example of no less than a prophet not possessing complete knowledge (Qur'ān, 18:6582). Also, the Qur'ānic formulation 'alif-lam-mīm' (e.g. Qur'ān, 2:1) is widely regarded as indicative of divine mystery beyond ordinary human knowledge, which should instill humility in the reader as a reminder of her or his epistemic fallibility. Further, the hadith literature is also replete with examples of the first generation of Muslims (the sahāba) constantly requiring and requesting guidance and correction from the Prophet, thereby indicating the fallibility of the 'best generation'. Finally, the epistemic fallibility of human beings is a theme emphasized by later scholarly luminaries. Hāmid al-Ghazālī, for example, famously argued in both his Deliverance from Error and his Incoherence of the Philosophers that rational faculties and demonstrative reasoning were limited because they could not achieve logically guaranteed knowledge. The upshot of this line of argument is that 
beyond the realm of revelation, human knowledge is always fallible and so liable to revision and possible correction in the light of new information.

Instrumentalism is the position that theories are first and foremost valued as tools to achieve certain goals. ${ }^{17}$ A tool, be it theoretical or material, may have been constructed with an incorrect metaphysics or with erroneous assumptions in mind, but that does not necessarily bear upon its usefulness to others. The Prophetic example of the use of the trench in warfare, which was sourced from Persian culture, is an example of openness to the use of tools apparently not of a revealed origin. This is also the import of the famous aphorism attributed to the Prophet, 'Seek knowledge even as far as China', indicating there may be knowledge of 'foreign' provenance that is useful to Muslims. The golden age of Islamic thought is also an excellent example of the borrowing and transformation of tools of 'foreign' provenance. Classical logic, mathematics, rhetoric and medical science, for example, were taken up and utilized with profit in the Arabic-Persian Muslim world despite their Greek origins, because it was recognized that despite the pagan metaphysical presuppositions often accompanying them, they could be powerful - and improvable - tools for solving problems relevant to Muslims and humanity in general.

Why should these lessons from the Qur'ān, the Prophetic teachings and from past scholars not be instructive to the microcosm of the Islamic economics community? It would seem to be both unfair and shortsighted to rule out court tout the economic theories, methodologies and methods of others simply on the grounds that it comes from 'secular' source or advocates 'secular' solutions to economic problems. If one interprets the Qur'ānic insights about plurality (noted above) as applying to the microcosm of scholarly economics community as much as it does to the macrocosm of the global community, then surely it behooves Muslim economists to learn from other schools of thought-via both their errors and successes, their bads and goods. To dismiss other perspectives on the a priori presupposition that one knows there is no success and no goodness in something implies the belief that God creates entities of literally no benefit

17 There are a number of different methodological conceptions of instrumentalism (Mäki, 1998). The definition used above incorporates all of them. to anyone in any respect. It also is suggestive of an intellectual arrogance that one can know everything about a multi-faceted school of thought, both now and its future course for all time, as if it were a simple fossil, never capable of change or new insights.

An approach that is open and values scientific diversity is not, nor should it be uncritical or relativistic, however. To uncritically accept as true or valuable all theories, methods and methodologies can only lead to intellectual chaos and incoherence. Also, to not subject alternative views to critical interrogation indicates a lack of respect for those views, as it suggests that such views are simply not intellectually worthy of engagement. Uncritical acceptance is just as unfair and shortsighted as intolerant claims to infallibility. In sum, modern Islamic economics must be respectful and value diversity within itself and with regard to the wider scholarly community of economics if it is to grow and prosper. Diversity and critical engagement is necessary in order to affirm, if only by means of contrast, what is essential and distinctive about Islamic economics, to discover new insights provided by others that may be useful to Islamic economics, and to learn from the mistakes made within and outside Islamic economics.

\section{CONCLUDING COMMENT}

Islamic economics as a modern academic discipline is still relatively young. As such, one should not expect its definition, its scope, its methods or its theoretical constructions, let alone its findings to be settled at this stage in its development. In fact, given that an essential feature of the discipline is its earnest moral motivation, its necessary appeal to religious texts, the grand, sprawling traditions of Islamic scholarship, and also its efforts to apply itself practically to a world often hostile to its ideals, one should not expect unanimity on any particular issue. There will, I venture to suggest, always be contestation over the substantive ethical foundations, over the proper relationship between theory and evidence, and over the validity and worth of particular practical interventions in the world, such as banking and finance. The disjunction between actual economic practices in Muslim-majority communities and the ideals of Islamic economics - be they theoretical or ethical - will be a perennial spur to critique and 
debate. If modern Islamic economics were to broaden its horizons to include an examination of not just the innovations in neoclassicism but also the heterodox schools of secular economics, this will increase the range of methods and theoretical tools that it may profitably utilize to serve its normative ends.

\section{REFERENCE}

Adnan, M. \& Muhamad. Agency Problems in Mud arrabah Financing: The Case of Sharia (Rural) Banks, Indonesia. IIUM Journal of Economics and Management, 15 (2): 219-243.

Ahmad, A. \& Shahed, A. 2010. Housing Finance of Australian Islamic Financial Service Providers (IFSPS): An Empirical Analysis From Sharī'ah Perspectives. IIUM Journal of Economics and Management, 18 (1): 1-43.

Al-Amine, M. 2008. Sukūk Market: Innovations and Challenges. Islamic Economic Studies, 15 (2): $1-22$.

Alatas, S. 1995. The Sacralization of the Social Sciences: A Critique of an Emerging Theme in Academic Discourse. Archives de Sciences Sociales des Religions, 40 (91): 89-111.

Al-Faruqi, I. 1982. Islamization of knowledge: The Problem, Principles and the Workplan. Herndon, USA: IIIT.

Ali, D. \& Myles, G. 2010. The Consequences of Zakat for Capital Accumulation. Journal of Public Economic Theory, 12 (4): 837-856.

Amin, R. \& Yusof, S. 2003. Allocative Efficiency of Profit Maximization: An Islamic Perspective. Review of Islamic Economics, 13: 5-21.

Arif, M. 1985. Towards a Definition of Islamic Economics: Some Scientific Considerations. Journal of Research in Islamic Economics, 2 (2): 79-93.

Asutay, M. 2007a. A Political Economy Approach to Islamic Economics: Systemic Understanding for an Alternative Economic System. Kyoto Bulletin of Islamic Area Studies, 1 (2): 3-18.

Asutay, M. 2007b. Conceptualisation of the Second Best Solution in Overcoming the Social Failure of Islamic Banking and Finance: Examining the Overpowering of Homoislamicus by Homoeconomicus. IIUM Journal of Economics and Management, 15 (2): 167-195.
Asutay, M. 2010. Locating the Moral Deficit in Islamic Finance Emerging Divergence between Aspiration and Realities of Islamic Moral Economy and Islamic Finance. Second Workshop on Islamic Finance: What Islamic Finance Does (not) Change, 17 March, EM Strasbourg Business School, Strasbourg, France.

Asutay, M. 2012. Conceptualising and Locating the Social Failure of Islamic Finance: Aspirations of Islamic Moral Economy vs the Realities of Islamic Finance. Asian and African Area Studies, 11 (2): 93-113.

Boudjellal, M. 2006. Three Decades of Experimentation: Rethinking the Theory of Islamic Banking. Review of Islamic Economics, 10 (1): 23-39.

Broome, J. 1999. Ethics Out of Economics. Cambridge University Press, Cambridge.

Caplin, A. \& Schotter, A. (eds). 2010. The Foundations of Positive and Normative Economics: A Handbook. Oxford: Oxford University Press.

Chapra, M. 2004. Mawlana Mawdudi's contribution to Islamic economics. The Muslim World, 94: 163-180.

Choudhary, M. 1994. A Critique of Modernist Synthesis in Islamic Thought: Special Reference to Political Economy. The American Journal of Islamic Social Sciences, 11 (4): 475-503.

Choudhary, M. 1999. Islamic economics and Islamic political economy. Managerial Finance, 25 (5): 1-3.

Choudhary, M. 2003. Islamic Political Economy. Review of Islamic Economics,13: 49-71.

Choudhary, M. 2006. Islamic macroeconomics? International Journal of Social Economics, 33 (1/2): 160-186.

Choudhury, M. 2008. Islamic Economics and Finance - A Fiasco. Middle East Business and Economic Review, 20 (1): 38-51.

Dusuki, A. \& Abozaid, A. 2007. A Critical Appraisal on the Challenges of Realizing Maqasid alShari'ah in Islamic Banking and Finance. IIUM Journal of Economics and Management, 15 (2): 143-165.

El Hawary, D., Grais, W. \& Iqbal, Z., 2004. Regulating Islamic financial institutions: The nature of the regulated. World Bank Policy Research Working Paper, No. 3227. 
Furqani, H. 2010. The Micro-foundations of Islamic Economics: Exploration of Key Terminologies. Ninth Australian Society of Heterodox Economists Conference. 6-7 December, Sydney, Australia.

Galbraith, J. 1967. The New Industrial State. Boston: Houghton Mifflin.

Haneef, M. \& Furqani, H. 2009. Developing the Ethical Foundations of Islamic Economics: Benefitting from Toshihiko Izutsu. Intellectual Discourse, 17 (2): 173-199.

Hasan, Z. 1998. Profit Maximization: Secular Versus Islamic. In Tahir, S., Ghazali, A. \& Agil, S. (eds). 1998. Readings in Microeconomics in Islamic Perspective. Kuala Lumpur: Longman.

Hasan, Z. 2002. Maximization Postulates and Their Efficacy for Islamic Economics. The American Journal of Islamic Social Sciences, 19 (1): 95118.

Hosen, M. \& Nahrawi, A. 2012. Comparative analysis of islamic banking products between Malaysia and Indonesia. International Journal of Academic Research in Economics and Management Sciences, 1 (2): 120-143.

Jan, S. 2011. Evaluating the Performance of Islamic Banks in Suggesting an Islamic Model of Development. Mimeo. Durham Centre for Islamic Economics and Finance, Durham University, UK.

Kahf, M. 1989. Zakat: Unresolved Issues in the Contemporary Fiqh. Journal of Islamic Economics, 2(1): 1-22.

Kahf, M. 2004. Islamic Banks: The Rise of a New Power Alliance of Wealth and Shari'a Scholarship. In Henry, C. \& Wilson, R. (eds). 2004. The Politics of Islamic Finance. Edinburgh: Edinburgh University Press.

Kasri, R. \& Kassim, S. 2009. Empirical Determinants of Saving in The Islamic Banks: Evidence From Indonesia. Journal of King Abdulaziz University: Islamic Economics, 22 (2): 3-23.

Keynes, J. 1936. The General Theory of Employment, Interest and Money. London: Macmillan.

Keynes, J. 1937. The General Theory of Employment. Quarterly Journal of Economics, 51 (2): 209-23.

Khan, F. 2010. How 'Islamic' is Islamic Banking? Journal of Economic Behavior \& Organization, 76: 805-820.
Khan, M. 1984. Macro Consumption Function in an Islamic Framework. Journal of Research in Islamic Economics, 1 (2): 3-25.

Khan, M. \& Mirakhor, A. 1989. The Financial System and Monetary Policy in an Islamic Economy. Journal of King Abdulaziz University: Islamic Economics, 1: 39-57.

Khan, M. 1991. The Future of Islamic Economics. Futures, April: 248-261.

Khan, W. 1989. Towards an Interest-Free Islamic Economic System. Journal of King Abdulaziz University: Islamic Economics, 1: 3-38.

Kuran, T. 1986. The Economic System in Contemporary Islamic Thought: Interpretation and Assessment. International Journal of Middle East Studies, 18 (2): 135-164.

Kuran, T. 1989. On the Notion of Economic Justice in Contemporary Islamic Thought. International Journal of Middle East Studies, 21: 171-191.

Kuran, T. 1995. Islamic economics and the Islamic subeconomy. Journal of Economic Perspectives, 9 (4): 155-173.

Kuran, T. 2004. Islam and Mammon: The Economic Predicaments of Islamism. New Jersey: Princeton University Press.

Mahdi, S. \& Al-Asaly, S. 1991. A Model of Income Determination in an Interest Free Islamic Economy. In Faridi, F. (ed.) 1991. Essays in Islamic Economic Analysis. New Delhi: Genuine Publications.

Mäki, U. 1998. Instrumentalism. In Davis, J., Hands, D. \& Mäki, U. (eds). 1998. The Handbook of Economic Methodology. Cheltenham, UK: Edward Elgar.

Malik, S., Malik,A. \& Mustafa, W.2011. Controversies That Make Islamic Banking Controversial: An Analysis of Issues and Challenges. American Journal of Social and Management Sciences, 2 (1): 41-46.

Metwally, M. 1992. A Behavioural Model of an Islamic Firm. In Tahir, S., Ghazali, A. \& Agil, S. (eds). 1992. Readings in Microeconomics: An Islamic Perspective. Petaling Jaya, Malaysia: Longman.

Mirakhor, 2007. Islamic Finance and Globalization: A Convergence? Journal of Islamic Economics, Banking and Finance, 3 (2): 11-72. 
Mirakhor, A. 2009. Islamic Economics and Finance: An Institutional Perspective. IIUM Journal of Economics and Management, 17 (1): 31-72.

Muqorobin, M. 2008. Journey of Islamic Economics in the Modern World. Proceedings of the Seventh International Conference on Islamic Economics. 1-3 April, Jeddah, Saudi Arabia.

Nagaoka S. 2012. Critical Overview of the History of Islamic Economics: Formation, Transformation, and New Horizons. Asian and African Area Studies, 11 (2): 114-136.

Nawawi \& Keller, N. 2004. Al Maqasid: Nawawi's Manual of Islam. Beltsville, MD: Amana Publications.

Parray, T. 2011. Islamic Modernist and Reformist Thought: A Study of the Contribution of Sir Sayyid and Muhammad Iqbal. World Journal of Islamic History and Civilization, 1 (2): 79-93.

Rahman, A. 2007. Islamic Banking and Finance: Between Ideals and Realities. IIUM Journal of Economics and Management, 15 (2): 123-141.

Rahman, F. 1964. Riba and Interest. Islamic Studies, 3(1): 1-43.

Rahim, D. 2007. An Analysis on Selected Fundamental Concepts in Islamic Economics. 2nd Islamic Economics Conference (iECONS 2007). 17-19 July, Kuala Lumpur, Malaysia.

Rosly, S. \& Sanusi, M. 2001. Some Issues of Bay $A l$ - inah in Malaysian Islamic Financial Markets. Arab Law Quarterly, 16 (3): 263-280.

Saeed, A. 1998. Idealism and Pragmatism in Islamic Banking: The Application of Sharì'ah Principles and Adjustments. Journal of Arabic, Islamic and Middle Eastern Studies, 4 (2): 89-111.

Saeed, A. 1999. Islamic Banking and Interest: A Study of the Prohibition of Riba and Its Contemporary Interpretation. Leiden, The Netherlands: Brill.

Shams, R. 2004. A Critical Assessment of Islamic Economics. HWWA Discussion Paper No. 281. Hamburg Institute of International Economics.
Siddiqi, M. 1993. Modern Reformist Thought in the Muslim World. Delhi: Adam Publishers \& Distributors.

Siddiqui, N. 2006. Islamic Banking and Finance in Theory and Practice: A Survey of State of Art. Islamic Economics Studies, 13(2): 1-48.

Simon, H. 1955. A Behavioral Model of Rational Choice. The Quarterly Journal of Economics, 69 (1): 99-118.

Šrámek, O. 2009. Islamic Economics: New Economic Paradigm, or Political Agenda? New Perspectives on Political Economy, 5 (2): 137-167.

Stilwell, F. 2006. Political Economy: The Contest of Ideas. Oxford: Oxford University Press.

Ünal, M. 2010. Shariah Scholars - A Network Analytic Perspective. Version 4.0.Funds@Work.

van Greuning, H. \& Iqbal, Z. 2008. Risk Analysis for Islamic Banks. Washington D.C.: The World Bank.

Veblen, T. 1898. Why is Economics not an Evolutionary Science? The Quarterly Journal of Economics, 12 (4): 373-397.

Wilson, R. 1998. The Contribution of Muhammad Baqir Al-Sadr to Contemporary Islamic Economic Thought. Journal of Islamic Studies, 9 (1): 46-59.

Yousef, T. 2004. The Murabaha Syndrome in Islamic Finance: Laws, Institutions and Politics. In Henry, C. \& Wilson, R. (eds). 2004. The Politics of Islamic Finance. Edinburgh: Edinburgh University Press.

Yusoff, M. 2006. Fiscal Policy in an Islamic Economy and the Role of Zakāt. IIUM Journal of Economics and Management, 14 (2): 117-145.

Zaman, A. 2011. Crisis in Islamic Economics: Diagnosis and Prescriptions. Eighth International Conference on Islamic Economics and Finance. 19-21 December, Doha, Qatar.

Zayd, N. 2006. Reformation of Islamic Thought. A Critical Historical Analysis. Amsterdam: Amsterdam University Press. 